Historic, Archive Document

Do not assume content reflects current scientific knowledge, policies, or practices. 


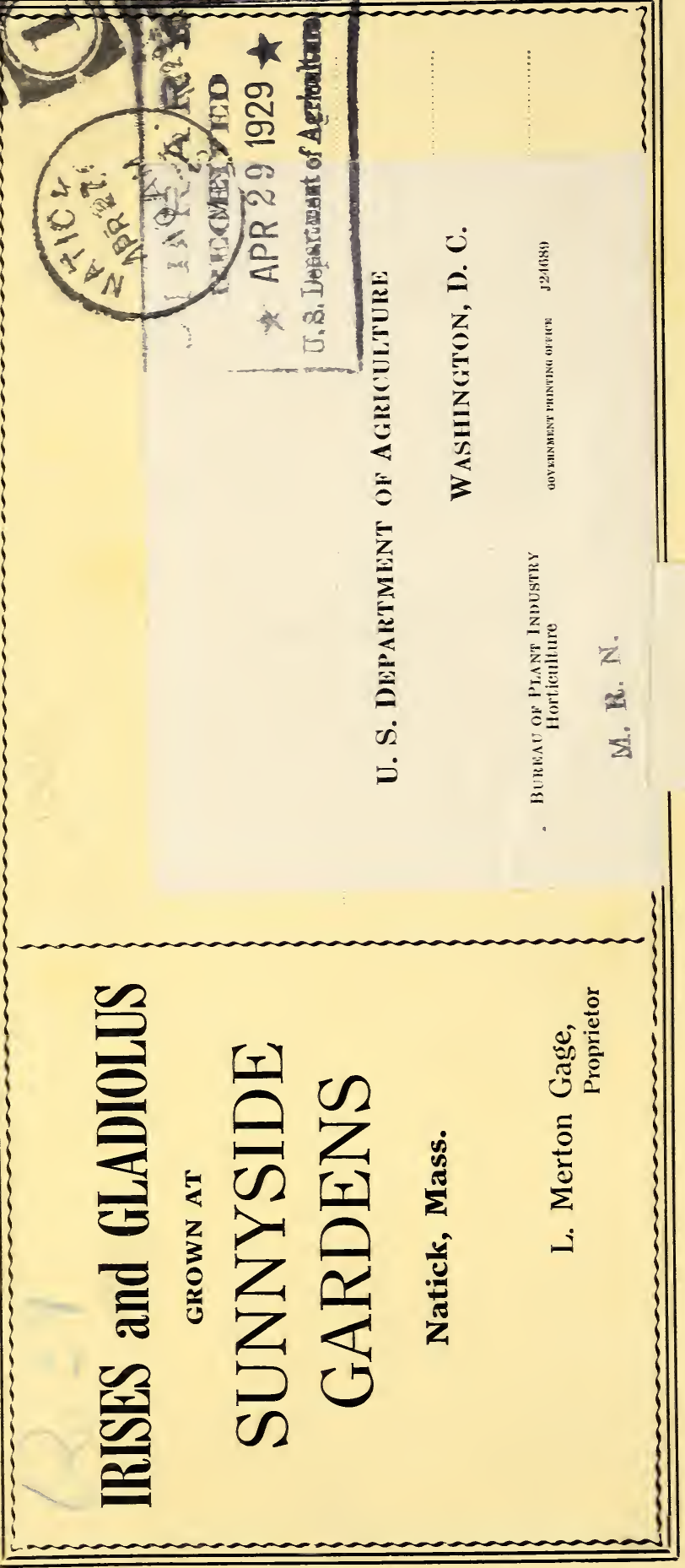




\section{SUNYYSIDE IRISES}

and

\section{GLADIOLIS}

I wish to call to your notice the fact that of the 194 Irises listed herewith not one is rated below 70 and all but 8 rate 75 and more, even tho the new rating of the 1927 Symposium of the American Iris Society reduced the rating on many varieties rated in the 1922 Symposium. This list, I think, will compare favorably with any high class catalog sent out this year, and we are going to continue to offer the best that we can obtain each year of the new things, retaining only the best of the older varieties until superseded by better new ones.

The gladiolus offered in this catalog are all originations of L. Merton Gage. Many of these glads are already well known in this country and abroad, and have taken many prizes at Exhibitions here and in Canada. The novelties offered are listed at reasonable prices, and are carefully selected for QUALITY from many thousand seedling bulbs.

\section{READ BEFORE YOU SEND IN YOUR ORDER}

Iy stock in some varieties is not large, so to make sure that you will get all the varieties you want send your order early with $25 \%$ of the amount, and the balance at the time of shipment, and I will hold them for you.

All orders must be accompanied with cash, but if to be sent C. O. D. remit $25 \%$ when ordering.

DISCOUNT. A discount of $10 \%$ will be allowed on orders amounting to $\$ 25.00$ or more.

SUBSTITUTES. Except where noted I will not substitute unless directed to do so. It is a good plan to make a second choice in case some varieties are sold out, especially late orders.

POSTAGE. All Iris sent prepaid, and when order aniounts to $\$ 5.00$ or more, insured at my expense.

\section{SCNYYSIDE GARDENS}

are located in Natick village, at the end of Harvard street extension. I am always home Sundays and Wednesdays, and visitors are always welcome during the blooming season, April 15th to June 15th. Come and see the new ones-"Grace Sturtevant," "Dolly Madison," "Vesper Gold," “Ariel," "Midgard," "Gabriel," "Alabaster," Andrews new white; "Ethereal Charm," "Evadne," "Mrs. Marian Cran," "Prairie Gold," "Proteus," said to be the largest flowered Iris in the world; "Rosado" and "W. R. Dykes" the new $\$ 100.00$ pure yellow Iris from England, "San Francisco," "Abora," "Moa," "Conchobar," "Zulu," "Sir Michael," "Wm. Mohr," "White and Gold," "Buto," "Coronation," (new deep yellow), "Nymph," "Louis Bel," "Cinnabar," "Sweet Sixteen," "Duchess Sarah," "Fismes," "Impressario," "Mother Machree," "Swazi." 
Irises will be shipped from late in June until the 15 th of September. The month of August is considered by many the best time to plant Irises. At this time the rhizomes are of good size and vigorous.

Join The Imerican Iris Society-Every new member receives the book "Irises For Beginners" which is alone worth the cost of membership, and you also receive four bulletins a year of interesting Iris news and information. Send dues $\$ 3.00$ to J. B. Wallace, Secretary, 129 Church St., New Haven, Conn.

\section{$1929-$ \\ Retail Price List oi the WORLD'S BEST IRIS}

with the 1927 Garden Ratings of the American Iris Society Those marked with an asterisk, (*) are the Exhibition ratings. The name of the originator with year of introduction is in parenthisis following the name of variety.

We are offering this year four new Irises from the gardens of Mr. E. G. Lapham, Elkhart, Indiana. Two of these we have grown in our own gardens for two years, and we are so pleased with them, and have such confidence in his judgement of what a good Iris should be that we are listing the set of four. Mr. Lapham is one of our new breeders and keeps careful records of his work along strictly scientific lines. (Mr. Laphams descriptions).

\section{E. G. LAPHAM IXTRODCCTIOXS}

BELLE PORTER, (Lapham 1929). The standards, livid brown slightly suffused with violet. Falls, violet carmine edged lighter with a lighter medial line. Hard to describe, but might be termed a blending of old rose and red. The coloring is quite striking and distinctire. A valuable landscape iris. Growth rampant.

Each $\$ 5.00$

CAMILLA DCBCAR, (Lapham 1929). Phlox pink to pale phlox pink. "This iris gives a much truer impression of real pink than any I know, and is really very delicate and beautiful, ret holds up well. It is also of vigorous growth and quite distinctive in its appearance as a plant. Its stems are well branched, starting low down about even with the drooping foliage; four branches and many blooms, up to TWELVE to a stem. Each \$5.00

ELPHEMIA, (Lapham 1929). Standards, cotinga purple. Falls prune purple to blackish purple. Similar tobut much superior and taller than Archeveque. Free flowering, a rapid grower, and stands up fine as a landscape iris. Each \$2.50

SOPHIE, (Lapham 1929). Manganese violet silghtly suffused with bronze. The flower is of beautiful shape and splendid substance. It has good height and size of bloom. Its second year from seed it gare two bloom stalks, and the third year, EIGHT. Rampant as to growth, and the freest blooming iris I have ever encountered. A self. 
We have added to our 1929 list 88 varieties of choice iris and the following appealed to us as particularly fine and outstanding,--Amarind, metallic bronze in nearly a self color, Caroline E. String. er, a very delicate light pink, in fact the lightest tone of pink we have seen, Crgnet, a creamy white plicata with delicate purple markings, Dolly Mad. ison, a darker, glorified Quaker Lady. Duchess Sarah, a lovely pale blue bi-color. Gabriel, Enormous flowers of clear steel blue with light violet-blue falls, Grace Sturterant, the richest coloring we have ever seen in an iris, brownish purple with crimson black falls and deep orange beard, Midgard, I like this much better than Mary Gibson. Mme. Henri Cayeux, this is another iris of gorgeous coloring, a red-violet bicolor, the falls almost deep crimson. Montaur, very rich coloring, Nebraska, a wonderful dark yellow of fine form, Solferino, beautiful lilac-red. The tallest in my gardens. Vesper Gold, a very beautiful shade of baryta yellow, rapid increaser. Swazi, one of the most beautiful of the violet bicolors, scarce.

\section{NEW AND STANDARD VARIETIES}

S2 AFTERGLOW (Sturt. 1819)

ALABASTER (Andrews 1926)

72 ALBICANS white species

ALICE OSGOOD (Sturtevant 1920)

AMARINI) (Andrews 1926)

75 AlAS species

91 AMBASSAIEELR (Vilmorin 1920)

85 ANT PAGE (Newlands 1919)

7 AXNA FARR (Farr 1913)

ANTOINE ANTONXETTE (Kunderd 1926)

AXYIE LAURIE (Moore 1927)

88 APHROIDTE (Dykes 1923)

81 ARCHEVEQUE (Vilmorin 1911)

83 ARGINNIS (Williamson 1925)

84 ARLINGTON (Simpson 1923)

*92 ASIA (Yeld 1920)

83 A'THENE (Sturtevant 1920)

77 AUTUII KIXG (Sass)

AUTUMY QUEEY (Sass)

81 A VALON (Sturtevant 1918)

i4 AZCRE (Bliss 1918)

87 ALCAZAR (Vilmorin 1910)

S9 BALLERIYE (Vilmorin 1920) extra

\begin{tabular}{|c|c|c|}
\hline 1 for & 3 for & 5 for \\
\hline$\$ . \mathbf{2 5}$ & $\$ \quad .60$ & $\$ \quad .90$ \\
\hline 5.00 & & \\
\hline $\begin{array}{l}.830 \\
.50 \\
.50\end{array}$ & .75 & \\
\hline ๖.00 & & \\
\hline .20 & 告 & .75 \\
\hline .60 & 1.50 & \\
\hline 1.50 & 4.00 & \\
\hline .40 & 1.00 & \\
\hline .75 & 2.00 & \\
\hline 5.00 & & \\
\hline 3.50 & & \\
\hline .20 & (50.50 & .90 \\
\hline .75 & 2.00 & 3.00 \\
\hline 1.00 & 2.50 & 3.75 \\
\hline 2.00 & $\overline{\boldsymbol{\delta}} .00$ & \\
\hline .40 & 1.00 & \\
\hline 1.00 & 2.500 & \\
\hline 1.00 & 2.50 & \\
\hline 1.50 & 4.00 & \\
\hline . & .60 & \\
\hline .25 & .60 & \\
\hline .75 & $\mathbf{2 . 0 0}$ & 3.00 \\
\hline .25 & .60 & \\
\hline 1.50 & t.00 & \\
\hline 2.00 & 5.00 & \\
\hline .35 & & \\
\hline .35 & .75 & \\
\hline .60 & 1.50 & \\
\hline 6.00 & & \\
\hline .30 & .75 & \\
\hline 6.00 & & \\
\hline 5.00 & & \\
\hline $\begin{array}{l}75 \\
.40\end{array}$ & & \\
\hline. \pm 0 & 1.0 & \\
\hline
\end{tabular}


1 for 3 for

$.60 \quad 1.50$

so CHALICE (Sturtevant 1924)

i5 CLEMENT IESORMES (Denis 1924)

is COL. CANDELOT (Millet 1907)

* s9 CONQLISTADOR (Mohr 1923)

COROXATIOY (Moore 1927) Large deep clear yellow

st CORRIDA (Millet 1914) Extra

s1 C. P. CONXELL (Fryer)

S3 CRIISOY GLOW (Perry 1924)

S5 CRLSADER (Foster 1913)

s3 CIGNET (Sturterant 1922)

DARLIYG IELLIE GRAY (Moore $192 \%)$

79 DALILA (Denis 1914)

จ. DAIOSEL (Morrison 1922)

\$. DELICATISSIMA (Millet 1914)

D. K. WILLIA.YSOY (Williamson)

*93 DOLLY UADISOY (Longfield 1927)

DRAGONFLY (Dykes) Siberica

st DREAII (Sturt. 191S)

Dr. C. H. IIAY (Fryer) very fine

¡2 Dr. AXIRIST (Fryer 1919)

DECHESS SARAH (Yeld 1924)

DCLCIYEA (Mohr 1925)

s1 E. C. SHAW (Fryer new) rery fine

S1 EDOLARD MICHEL (Terdier 1901)

; EGLAIOTR (Hort 1921)

EIIPER0R (Tallace) Sibirica

\$6 ESPLENDID0 (Mohr 1924)

ETHEREAL CHARII (Rounds 1926)

ECPHEMIA (Lapham 1928)

5: EVADYE (Bliss 1924) extra

is FAIR I (Kennicott 1905)

FIRMAMENT (Groschner 1920) early

; FRAYKLIY BEIYOI (Perry 1923)

S; GABRIEL (Bliss 1921)

S2 GAVIOTA (Mohr 1924)

ss GE0. J. TRIBILET (Williamson 1926)

S3 GEORGIA (Farr 1920)

90 GERIIIIE PERTHTIS (Millet 1924)

it GERUAIICA purple self (Species)

s. GOLD IMPERIAL (Sturt. 1924)

*91 GRACE STIRTETANT (Bliss 1926)

\$1 GRAPTA (Williams on 1925)

s6 GLOWIXG EMBERS (Sturterant 1923)

$1.50 \quad 3.50$

.5) ...0

1.50

5.00

.85

.20

3.00

.35

1.00

5.00

.35

1.00

.60

.35

15.00

1.50

.50

2.00

.85

3.50

1.50

.60

.75

1.00

$\begin{array}{ll}.50 & .90\end{array}$

.75

.

.75

1.50

.15

1.00

3.50

1.25

5.00

.75

1.00

1.50

2.00

.35

.75

.35

1.50

.2.00

5.00

อ..50

.25 .60

1.00

.30 .75

$.60 \quad 1.50$

7.50

.7200

3.50

.50

9.00

5.00

응

2.00

14.00

.60

5.00

2.5.00

.50

1.00

3.50

\$1 HALO (Yeld 1917)

s. HARMONY (Dykes 1923)

83 HARRIET PRESBY (Presby 1922)

.50

1.09

1.00

.3.

.50

1.25

2.50

2.50

.75

1.00 HFLEY ERAYCIS

*? HELENE KOEHLER (Koehler 1924)

81 HERMONE (Newlands 1920)

1.002 .50

HERIOSA (Dean 1923)

1.002 .00

1.50

1.50 
HORIZON (Morrison 1925)

HYIROYEL (Williamson 1928)

S4 IMPERATOR (Cayeux 1923) fine

S3 ISIS (Bliss 1920)

S3 JACQTELIYE GLILLOT (CayeuX 1924)

S1 JUNIATA (Farr 1909)

* is JUNoxIA (species) very fine

*80 KALOS (Sass 1924)

73 KITHERINE FRIER (Fryer 1917)

KIXGFISHER BLCE (Wallace 1924) sib.

S0 KOCHII intermediate

S3 LAIY BYNG (Bliss 1922) EXTRA

LADY GODIVA Siberian

LADY LILLIAY (Burchfield)

ss L. A. WILLIAISSOX (Williamson 1918)

*SS LEONATO (Hort 1922)

*S6 LEVERRIER (Denis 1917)

*SS LORD OF JUNE (Yeld 1911)

79 LULW0RTH (Dykes 1924)

79 LEON TREXAYCE (Bliss 1922)

So MAGNIFICA (Vilmirin 1920)

79 MAGNIFICENT (Fryer) EXTRA

*SS MAJESTIC (Bliss 1923)

S1 MARSH MARIGOLD (Bliss 1919)

85 MARY GIBSON (Perry 1924)

S1 IARY ORTH (Farr 1920)

87 MEDRAYO (Vilmorin 1920)

IIDGARD (Sass, new) EXTRA

So MIDWEST (Sass 1922)

87 MILDRED PRESBY (Farr 1923) FINE

73 Vime. BOCLET (Denis 1919)

ss Mme. CECILE BOUSCANT (Millet 1923)

i4 Mme. CHEREAU (Lemon 1844)

S3 IIme. CHERI (Sturt. 1918)

so Ime. CHOBAL'T (Denis 1916)

8. Mme. HEYRI CAYECX (Cayeux 1925)

*\$4 Ime. J. VERYOCX (Millet 1921)

59 MOLIERE (Vilm. 1920)

\% MONSIGNOR (Vilm. 1907)

IOX'T ILR (Hall 1923) EXTRA

91 IORYING SPLENDOR (Shull 1923)

YOTHER MACHREE (Moore 1927)

S4 HOTHER OF PEARL (Sturt. 1921)

74 Yrs. ALLAY GRAY (Foster 1919)

79 Mrs. HARIAN CRAX (Perry 1923)

Irs. NAGLEI (Fryer)

Irs. RAPP

is MIS. WALTER BREWSTER (Vilm. 1922)

7 Irs. W. E. FRYER (Fryer)

YADIXE (Fryer 1920)

YEBRASKA (Sass 1927) EXTRA

79 NEPTLNE (Yeld 1916)

S0 NUBHAY (Sturt.)

S2 OIDAROLOC (Andrews 1924)

is 0LIVER PERTHUIS (Millet 1921)

S3 OPERA (Vilm. 1916)

*S2 OPHIR GOLD (Andrews 1925)

OPORTO (Yeld 1911)

PAPILLON (Dykes) Sibirica
1 for 3 for 5 for

3.50

1.50

1.50

2.00

$4.00 \quad 6.00$

$2.00 \quad 5.00$

.250 .50

1.00

1.50

.50

1.002 .50

.35 .75

1.50 2.00

.50

2.00

.35

2.00

.60

.60

1.00

.60

.75

2.50

4.00

.50

2.00

.50

.50

6.00

.50

1.00

$1.00 \quad 2.50$

$.35 \quad .75$

5.00

.20

.75

.05

.50

.60

5.00

.75

.35

.20

4.00

2.00

2.00

.25

.15

4.00

1.00

.20

.90

1.25

1.50

1.50

1.50

2.00

6.00

3.00

9.00

1.25

5.00

1.00

.75

.75

.50

.75

5.00

5.00

.50

.35

.50

.60

.20

.20

5.00

.35

.75

2.50

.75

.35

1.00

.20

1.00
$.50 \quad .75$

.50

.75

.75

.50 
SS PALLIDA DALMATICA Species

it PARISIAYA (Vilm. 1911)

*91 PFERLESS (Dykes 1924)

PERRY'S BLIE Siberian

St PHYLLIS BLISS (Bliss 1919)

PIXK Ime. CHEREAL (?)

90 PIONEER (Bliss 1924) EXTRA P. L. BATTET (Fryer's pink)

St PRAIRIE GOLD (Sass)

SS PRIIROSE (Sturt. 1923)

SO PRIYCE CHARMIYG (Sturt. 1924)

1 for

$.10 \quad 1.00$

$.35 \quad .75$

20.00

90 PRINCESS BEATRICE (Barl) true .ö0

80 PRIYCESS OSRA (Bliss 1922)

Proi. SEELIGER (Koehler 1923)

76 PROSPERITI (Sturt. 1,24)

S2 PROSPERO (Yeld 1920)

S0 PROTECS (Newlands 1924)

S4 PROSPER LACGIER (Verdier 1914)

\% QUAKER LADY (Farr 1909)

SS QCEEN CATARIYA (Sturt. 1918)

it QUEEY OF MAY (Salter 1859)

RAMONA (Mohr 1924) Fine

S7 RHEINGALPERLE (G. \& K. 1917)

So RIALGIR (Sturt. 1924)

S3 ROBERT W. WALIACE (Perry 1923)

S4 ROSALBA (Bliss 1919) Landscape

S3 SEMIYOLE (Farr 1920)

S4 SAY GABRIEL (Dean 1921)

*91 SAITA BARBARA (Mohr 1925)

S5 SAPPHII) (Dykes 1922) EXTRA SENSATIOY (Cayeux 1925)

St SHEKIYA (Sturt. 1918)

SHERBERT (Sturt. 1918) Fine

76 SHEPWIY WRIGHT (Kohankie 1915)

S2 SILVER RIBBOY (Williamson 1926)

SYOW (Bales)

SYOW QUEEY Sibirica

S5̆ SOLFERIYO (Cayeux 1925)

SOPHIE (Lapham)

90 Souv.d. LOETITIA IICHACD (Millet 1923) A Wonderful Iris

ss Souv.d. Mme. GALDICHAC (Millet 1914) Extra Fine

S2 SUXSE' (Denis 1919) Fine

S6 SLSA BLISS (Bliss 1922)

*S9 SWAZI (Bliss 1922)

S7 SWEET LAVEYDER (Bliss 1919)

\&? TITAN (Bliss 1921)

7TROJAYA Species

TROJANA-STRIYGER (Sass)

TREE BLEE (Fryer) Sibirica

St TROOST (Denis 1908)

*S1 TRUE CHARY (Sturt. 1920) Extra

S2 VALERY MAYET (Denis 1912)

S1 VELOCTE (Vilm. 1924)

\$9 VESPER GOLI) (Williamson 1927)

S0 WHITE KNIGH'T (Saunders 1916)

\$1 WHITE QUEEX (Geylenkek 1918)

S0 WILD ROSE (Sturt. 1921)

WIYOYA (Burchfield)
.35

.50

.60

2.50

.35

2.00

2.00

2.00

1.50

.50

.50

.50

4.00

.3.

.25

.50

.25

.75

1.50

2.00

3.00

.75

.40

2.00

4.00

.75

20.00

.35

.35

.75

1.25

1.50

$\begin{array}{rr}7.00 & 10.00\end{array}$

.75 1.00

5.00

5.00

$1.25 \quad 1.75$

1.25

1.00

.75

1.00

.50

1.25

.60

1.75

5.00

$2.00 \quad 3.00$

1.001 .50

2.00

.75

$.75 \quad 1.00$

$.25 \quad .60$

.75 1.50

$1.00 \quad 2.00$

.2506

3.00

10.00

2.50

3.50

.75 2.00

$.75 \quad 2.00$

1.002 .50

15.00

.50

1.25

2.50

$.30 \quad .75$

$\mathbf{2 . 5 0} 6.00$

$.25 \quad .60$

.250

$1.00 \quad 2.50$

$.40 \quad 1.00$

1.00

5.00

.40

.25

1.00

1.25

1.00

1.00 
79 W. J. FRYER (Fryer 1917)

1 for 3 for 5 for

WHITE and GOLD (Nicholls 1928)

$\begin{array}{lll}.30 & .75 & 1.00\end{array}$

S1 ZADA (Emigholz 1926) Best White

76 ZOUAVE (Vilm. 1922)

$1.00 \quad 2.50 \quad 3.75$

it ZCA (Crawford 1914) intermediate

S2 ZWANENBCRG (Denis 1909) early

\section{GLADIOLCS OF MERIT}

Originated by

L. MERTON GAGE

\section{IN'TRODUCTIONS FOR 19:9}

AXNA GAGE. Enormous creamy white flowers tinted with pink that bloom all around the spike, like a hyacinth. Each .............\$2.00

DOROTHY BISHOP. White thickly splashed with tyrian rose, and has a large rose red blotch in the throat. The flowers are very large, and the spike is tall but graceful. Altogether one of the most gorgeous glads yet introduced. Each ...... \$2.00

EDXA GAGE HICKS. A beautiful soft salmon pink (La France) with rose red blotches on the lower petals. Tall, straight spike, good size flowers of fine substance and slightly ruffled, 6 to 8 open at one time. Each ............... \$2.

GRACE CLARK. Lovely prim, grandiflorus. The color is soft barium yellow with a buff lip. A most distinctive and exquisite flower of good substance. Fine for cutting. Each ....... \$2.00

KATHERINE GAGE. I consider this the finest large-flowering pink gladiolus yet introduced. Very large wide open flowers of fine form and substance, perfectly placed on a tall straight spike. Pure deep geranium pink with a pure white throat. Each ..................... \$5.00

Xo. 10,000. This is one of my tallest varieties. It is a seedling of Mrs. Dr. Norton, with smaller flowers, but more are open at a time-8 to 10 with over 20 buds. The color is pale barium yellow or creamy white, flushed cameo pink. This beautiful gladiolus attracted much favorable attention at the Boston Show last August. Each . . \$5.00

one each of the above six varieties for $\$ 15.00$

\section{NEW VARIETIES FOR 1928}

IRS. ETHELYY ROSE KLEITZ. Prim, grandiflorus. Rose doree with an undertone of white shading to shrimp pink. Lower petals pale chalcidona yellow. Dainty and beautiful. Each . . \$2.00

BETTY GAGE. Good size golden yellow flowers of good form and substance. 4 to 6 open at a time, fine spike and a strong grower. Each . . \$2.00

MME. EUGENE DECISY. Pale congo pink flaked with peach red; lip straw yellow. Tall straight spike with many flowers open at a time. Each $\$$.35 
IIRS. H. BROMLEY AMBLER. Orange chrome, the lower petals lit with bright grenadine pink. The richest of all red glads. Each . . . . . . \$ \$.50

LEOX GAGE CARL. Rose color; throat white with a stripe of amaranth purple thru center of lower petals. Each .................. \$ ..35

TOLOA. Yellow overlaid with grenadine pink; pinard yellow lip with a line of the same color thru the center of each petal. Large well open flowers, straight spike. A gorgeous and beautiful combination of these colors. Each . . . . . . . $\$ \mathbf{\$ 2 . 5 0}$

one bulb each of above six novelties $\$ 10.00$

\section{FORMER INTRODLCTIONS}

ALMA GLCCK. Prim. grandiflorus. Clear, brilliant peach red. There is a splash of scarlet red in the throat surrounded with a corona of sulphur yellow. Excellent for cutting and Landscape use.

1st size bulbs 1ə̌c each. ..........\$1.50 doz. 2nd. size bulbs 10c each...........\$1.00 doz.

AFRICA. Pomegranate purple. There is a large blotch of Bordeaux tipped with white in the throat which appears to be black at a distance. Dozen $\$ \mathbf{\$ 2 . 5 0}$ Each ..................... \$ .25

BROXZE BEAUTY. Ground color Colonial buff and so closely overlaid with fine lines of old rose that the effect is a light bronze color. Dozen $\$ 3.50$ Each

CYNTHIA CLOUGH. Geranium pink; three lower petals scarlet red with a fine line of white running thru the center. Very fine. Dozen $\$ \mathbf{2 . 0 0}$ Each ....................... $\$$

DR. JOHN A. MILLS. Very tall spike of good size flowers. White, edged with rose pink with blotches of rose red on three lower petals. Eight flowers open at a time. A strong grower and increases rapidly from bulblets. Very popular with visitors at my gardens. Each .............\$\$1.00

MARJORIE GAGE. A seedling of "Mrs. Frank Pendleton" which it resembles in form. Pure white with the characteristic deep red blotch that makes "Pendleton" so impressively attractive. Dozen $\$ \mathbf{2 . 5 0}$ Each . . . . . . . . . . . . . \$ .25

MACRICE FCLD. This is one of the largest glads yet introduced, measuring from 6 " to $61 / 2$ " across. Always dependable under different kinds of soil and climatic conditions, withstanding the hottest sun without wilting. Fine spike of rich pink, (rose doree) without streaks or blemish with a small broken blotch of tyrian rose on a pure white throat. First Prize for largest flowers, Boston, 1925. Dozen \$3.50. Each ........... \$ .35 2nd. size, Dozen \$..50 Each . . . . . . . .

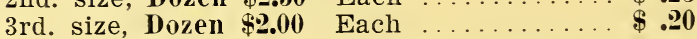

MOLLY BURYHAM. Pure white flushed cameo pink; marguerite yellow lip. Very large and beautiful.

1st. size, each $\ldots \ldots \ldots \ldots \ldots \ldots \ldots \ldots \ldots \$$ \$ .50

2nd. size, each ................ .35 
WM. R. TLCKER. Scarlet shading to purple-red, with a purple edge. Quite unusual color combination.

1st. size, each . . . . .

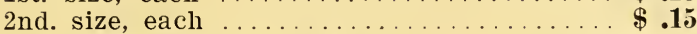

One large bulb of each oi $\mathrm{my}$ former introductions (9)

SEEDLING OFFER-With every order amounting to $\$ 3.00$ or over I will include one of my new, unnamed Seedlings. I am doing this to get your opinion of these Seedlings before I offer them under Name, as I only intend to name those that are really worthy and distinctive.

I am again offering this year a few hundred bulbs of my unbloomed seedlings (that have never yet come into bloom). These bulbs were raised from hand-crossed seed of the finest named varieties, and some of my own best varieties. In $1924 \mathrm{I}$ sold to Mr. John H. Paton, Goldedge Gladiolus Gardens, North Attleboro, Mass., 100 bulbs of these seedlings. Last year he purchased 500 bulbs and this year he has ordered 1500 . With flowers from this stock he took FIRST PRIZE for best seedling variety at the Exhibition of the North Attleboro Garden Club Show, 1924. First and second PRIZES, and the American Gladiolus Society's BLUE RIBBON in the seedling class, at their 1925 Show, and refused an offer of $\$ 75.00$ for a bulb of one of these prize winners.

My gladiolus novelties are much lower in price than you would have to pay for the same quality of certain Western specialists. I have paid outrageous prices for some of the recent years World Beaters, and I suppose some of you have had the same experience.

\section{NOTICE-CHOICE IRISES WANTED IN EXCHAYGE FOR GLADS}

\section{All Orders Sent Pre-Paid.}

N. B.-A membership in the American Gladiolus Society brings you every month The Gladiolus Review, a most interesting 32-page Magazine devoted to Gladiolus news and information. Send $\$ 2.00$ to Roscoe Huff, Secretary, Goshen, Indiana.

The Flower Grower published by Madison Cooper, Calcium, New York, $(\$ 2.00$ a year $)$ is, in my opinion, the best Floral Magazine published. 
